\title{
Isolation and characterization of bacteriophages with lytic activity against common bacterial pathogens
}

\author{
R. K. Shende ${ }^{1}$, S. D. Hirpurkar ${ }^{1}$, C. Sannat ${ }^{1}$, Nidhi Rawat ${ }^{1}$ and Vinay Pandey ${ }^{2}$
}

1. Department of Veterinary Microbiology, College of Veterinary Science \& Animal Husbandry, Anjora Chhattisgarh Kamdhenu Vishwavidyalaya, Durg, Chhattisgarh, India; 2. Department of Animal Nutrition, College of Veterinary Science \& Animal Husbandry, Anjora, Chhattisgarh Kamdhenu Vishwavidyalaya, Durg, Chhattisgarh, India.

Corresponding author: C. Sannat, e-mail: csannat@rediffmail.com

Co-authors: RKS: rshende786@rediffmail.com, SDH: smpuhir@yahoo.com,NR: dr_nidhirawat@yahoo.com, VP: drvinaypandey26@gmail.com

Received: 26-04-2017, Accepted: 25-07-2017, Published online: 23-08-2017

doi: 10.14202/vetworld.2017.973-978 How to cite this article: Shende RK, Hirpurkar SD, Sannat C, Rawat N, Pandey V (2017) Isolation and characterization of bacteriophages with lytic activity against common bacterial pathogens, Veterinary World, 10(8): 973-978.

\begin{abstract}
Aim: Present investigation was conducted to isolate and characterize bacteriophages with lytic activity against common bacterial pathogens.

Materials and Methods: A total of 60 samples of animal waste disposal from cattle (42) and buffalo (18) farms were collected from three different strata, i.e., top, mid, and bottom of collection tank. Samples were primarily subjected to rapid detection methods, and then isolation of phage was done by double agar layer method using Bacillus subtilis (BsH) and Escherichia coli $(\mathrm{EH})$ as host system. Phages were characterized on the basis of plaque morphology, temperature, $\mathrm{pH}$ susceptibility, and host range.
\end{abstract}

Results: Recovery of phages was higher from dairy cattle farm waste (78.57\%) as compared to buffalo farm waste (72.22\%) and bottom layer of tank showed maximum recovery. Bacillus subtilis $(91 \%)$ supported the growth of more phages as compared to E. coli (9\%). Three different phage morphotypes were observed each against Bacillus subtilis $\left(\mathrm{BsHR}_{1}, \mathrm{BsHR}_{2}\right.$, and $\mathrm{BsHR}_{3}$ ) and E. coli $\left(\mathrm{EHR} 1, \mathrm{EHR}_{2}\right.$, and $\mathrm{EHR}_{3}$ ). Mean phage titer of above six phage isolates ranged between $3 \times 10^{10}$ and $5 \times 10^{12}$ plaque forming units $/ \mathrm{ml}$. Viability of phages was by, and large unaffected at $70^{\circ} \mathrm{C}$ within $2-3$ min, and phage isolates were completely inactivated below $\mathrm{pH}_{3}$ and above 11 . Coliphage $\mathrm{EHR}_{1}$ had widest host range followed by $\mathrm{BsHR}_{1}$ and $\mathrm{BsHR}_{2}$ while $\mathrm{EHR}_{2}, \mathrm{EHR}_{3}$, and $\mathrm{BsHR}_{3}$ had low lytic activity.

Conclusion: It could be concluded from the present study that the Bacillus and Coli phage has wide host range and thus exhibits the potential to be used as drug substitute tool against common bacterial pathogens.

Keywords: Bacillus subtilis, bacteriophage, Escherichia coli, host range, sewage.

\section{Introduction}

Bacteriophages are viruses which have the ability to multiply only in bacterial cells, and they are detectable almost everywhere where live bacteria exist [1]. The environment populated by bacterial hosts such as soil, sewage, and animal secretions are unique source of all types of phages, offering the possibility to isolate them for therapeutic purposes [2]. In current scenario, serious medical and social problem results from the increasing antibiotic resistance of bacterial strains [3]. At the same time, pharmaceutical industries are withdrawing from research and development on new antibiotics due to unprofitability of the venture and the risks of development of resistance in bacteria [4], which has generated

Copyright: Shende, et al. Open Access. This article is distributed under the terms of the Creative Commons Attribution 4.0 International License (http://creativecommons.org/licenses/ by/4.0/), which permits unrestricted use, distribution, and reproduction in any medium, provided you give appropriate credit to the original author(s) and the source, provide a link to the Creative Commons license, and indicate if changes were made. The Creative Commons Public Domain Dedication waiver (http:// creativecommons.org/publicdomain/zero/1.0/) applies to the data made available in this article, unless otherwise stated. interest in alternatives over conventional and current system of microbial control. Lytic phages are the possible replacement for antibiotics to treat bacterial infections not responding to conventional antibiotic therapy [5].

The application of phages to control a certain bacterial pathogen is complicated by the high degrees of phenotypic diversity within populations of both phages and bacteria [6]. Consequently, individual strains of a pathogen may be more or less susceptible or even resistant to different co-occurring phages. Before therapeutic application, it is necessary to understand in detail the phage and host interaction, which is affected by both biological and physical factors [7]. The biological aspect is related to bacterial resistance, whereas temperature and $\mathrm{pH}$ are the main physical factors affecting the phage adsorption and bacterial growth.

Therefore, the present investigation was conducted to isolate and characterize lytic bacteriophages from the dairy farm waste using Escherichia coli and Bacillus subtilis as host system and to assess their in vitro susceptibility in common bacterial pathogens isolated from clinical cases. 


\section{Materials and Methods}

\section{Ethical approval}

Ethical approval was not necessary to pursue this research work.

\section{Location of study}

The present study was conducted at the Department of Veterinary Microbiology, College of Veterinary Science and Animal Husbandry, Anjora, Durg, Chhattisgarh, India.

\section{Host bacteria}

B. subtilis and E. coli obtained from sewage were used as primary hosts for the isolation of phages.

\section{Collection and processing of waste water samples}

The samples of animal waste disposal constituting various body excretions of cows (42 nos.) and buffaloes (18 nos.) were collected in sufficient amount from three different strata, i.e. top, mid (15 cm deep from top), and bottom ( $45 \mathrm{~cm}$ deep from top) of collection tank. For this purpose, $30 \mathrm{~cm}$ long, sterile disposable pipette, pipette bulb, and conical flasks were used.

Samples were processed as per the method given by Jothikumar et al. [8] with slight modifications. Samples were spun gently in a homogenizer for $3 \mathrm{~h}$ continuously and then centrifuged at $3000 \mathrm{rpm}$ for $20 \mathrm{~min}$. The supernatant was collected and recentrifuged at $5000 \mathrm{rpm}$ for $20 \mathrm{~min}$ in refrigerated centrifuge (Remi C-24). Then, supernatant was filtered through a $0.45 \mu \mathrm{m}$ millipore syringe filters, and filtrate was tested for the presence of lytic activity against $B$. subtilis and E. coli.

\section{Isolation of bacteriophage}

Turbidity reduction and streak plate technique were used as preliminary methods for screening of lytic activity of phages. Turbidity reduction method was performed as per protocol of Harrigan and McCance [9] with slight modifications. $1 \mathrm{ml}$ chloroform was added in $5 \mathrm{ml}$ of processed sewage sample, then mixed and centrifuged at $3000 \mathrm{rpm}$ for $20 \mathrm{~min}$. $1 \mathrm{ml}$ supernatant was transferred in $5 \mathrm{ml}$ broth culture of bacteria. Whereas in streak plate method, processed samples were inoculated over surface of bacterial lawn on nutrient agar plates. Next day plates were examined for the presence of plaques or any lytic activity on bacterial lawn. The test was repeated thrice before the sample is adjudged as negative.

On the basis of clear plaque morphology, samples were selected for phage lysate preparation by more sensitive double agar layer (DAL) method as described by Adams [10]. In a sterile vial, $500 \mu 1$ of filtrate was mixed with $500 \mu \mathrm{l}$ of $6 \mathrm{~h}$ old bacterial culture, and $2.4 \mathrm{~g} / \mathrm{L} \mathrm{MgCl}_{2}$ solution was added to enhance the adsorption of phage over bacterial surface. Then, it was kept on a shaker in gentle speed for $20 \mathrm{~min}$ and then added to test tube containing $2.5 \mathrm{ml}$ of molten soft agar held at $45^{\circ} \mathrm{C}$ in a water bath. The mixture was swirled, poured onto lactose agar basal plates, allowed to solidify and then incubated at $37^{\circ} \mathrm{C}$ up to $48 \mathrm{~h}$. Plates were observed at interval of $6,12,24$, and $48 \mathrm{~h}$ for the development of plaques. Phage lysate was purified by two consecutive single plaque isolation cycle and propagated on the corresponding bacterial host strain. Different phage lysates were designated by the laboratory identification number as BsHR for B. subtilis phages and EHR for E. coli phages.

\section{Characterization of phages \\ Host range determination}

Freshly recovered phages were tested against pathogenic bacteria, namely, Staphylococcus aureus, Salmonella spp., Pseudomonas aeruginosa, E. coli, Proteus spp., and Klebsiella spp. isolated from different clinical samples.

\section{Plaque morphology}

Morphology of plaque was recorded according to their size, edge, and boundaries [11] and was noted as small (under $2 \mathrm{~mm}$ ), medium (2 $\mathrm{mm}$ ), and large (larger than $2 \mathrm{~mm}$ )/clear or diffused type plaques.

\section{Effect of temperature and $\mathrm{pH}$}

Viability of phage was tested at $70^{\circ} \mathrm{C}$ temperature when exposed for 1, 2, and $3 \mathrm{~min}$. Phage viability before and after heat treatment was adjudged by DAL method and any reduction in viability of phage was recorded. Similarly, the effect of $\mathrm{pH}$ (3-11) was seen on viability of phages in broth.

\section{Titration of phage lysate}

Phage lysate was prepared as per protocol of Jothikumar et al. [8] with slight modification. Briefly, phage stock $(100 \mu 1)$ was mixed with $200 \mu$ l of respective host bacterial culture $\left(3 \times 10^{7}\right.$ to $\left.1 \times 10^{8} \mathrm{cfu} / \mathrm{ml}\right)$. Then, $2.4 \mathrm{~g} / \mathrm{L}$ of $\mathrm{MgCl}_{2}$ was added and kept for $20 \mathrm{~min}$ on shaker adjusted at a gentle speed. The suspension was then mixed into $2.5 \mathrm{ml}$ molten soft agar kept at $45^{\circ} \mathrm{C}$ in water bath and incubated up to $48 \mathrm{~h}$ at $37^{\circ} \mathrm{C}$. Confluently, lysed plates were selected and the top agar was scrapped with $5 \mathrm{ml}$ of lactose broth. Scrapings were pooled and 2-3 drops of chloroform were added and kept for $10 \mathrm{~min}$ and then centrifuged at $5000 \mathrm{rpm}$ for $20 \mathrm{~min}$ in a refrigerated centrifuge (Remi C-24). Supernatant was filtered through $0.45 \mu \mathrm{m}$ Millipore syringe filter and filtrate was used as lysate. Ten-fold serial dilution of the phage lysate in normal saline was prepared and subjected to plaque formation by DAL method. Phage titer was expressed as plaque forming units (PFU/ml) and determined by following formula:

$\mathrm{PFU} / \mathrm{ml}=$ Number of plaques $\times$ Dilution factor

\section{Results}

\section{Phages isolates}

Recovery of phages was slightly higher in dairy cattle farm waste as compared to buffalo farm waste, and concentration of phage was greater in bottom and middle layer than superficial layer of tank (Table-1). Lytic activity shown by turbidity reduction method 
Table-1: Recovery status of lytic phages.

\begin{tabular}{llccc}
\hline $\begin{array}{l}\text { Sources of } \\
\text { sample }\end{array}$ & Strata of sampling & Number of samples & \multicolumn{1}{c}{$\begin{array}{c}\text { Lytic activity of phage by rapid } \\
\text { screening method }\end{array}$} \\
\cline { 3 - 5 } & & & $\begin{array}{c}\text { Turbidity reduction } \\
\text { method (\%) }\end{array}$ & $\begin{array}{c}\text { Streak plate } \\
\text { method (\%) }\end{array}$ \\
\hline Dairy cattle farm & Top & & $6(42.8)$ & $6(42.8)$ \\
& Middle & 14 & $13(92.8)$ & $7(50)$ \\
& Bottom & 14 & $14(100)$ & $12(85.7)$ \\
Buffalo farm & Total & 14 & $33(78.57)$ & $25(59.62)$ \\
& Top & 42 & $3(50)$ & $0(0)$ \\
& Middle & 6 & $4(66.7)$ & $3(50)$ \\
& Bottom & 6 & $6(100)$ & $5(83.3)$ \\
& Total & 6 & $13(72.22)$ & $8(44.44)$ \\
\hline
\end{tabular}

was more $(76.66 \%)$ as compared to streak plate method $(55 \%)$ and DAL method (55\%). Further, comparison of streak plate method with DAL method revealed $100 \%$ correlation.

During the present study, a total of 33 phage isolates were obtained. For each prime host, three different phage types were assigned on the basis of plaque morphology. Numbers of phage strains recovered against $B$. subtilis and E. coli were $30(91 \%)$ and $3(9 \%)$, respectively (Table-2). Three different phage morphotypes each against $B$. subtilis $\left(\mathrm{BsHR}_{1}, \mathrm{BsHR}_{2}\right.$, and $\mathrm{BsHR}_{3}$ ) and E. coli $\left(\mathrm{EHR} 1, \mathrm{EHR}_{2}\right.$, and $\mathrm{EHR}_{3}$ ) were reported (Figures-1-4).

\section{Characteristics of phages}

No significant effect due to $\mathrm{pH}$ on viability of phage isolates was recorded. The isolates appear to be stable at the $\mathrm{pH}$ range 5-9 but inactivation is evident at the very low $(\mathrm{pH} 3)$ and very high $\mathrm{pH}$ levels ( $\mathrm{pH} 11)$. Phage isolates $\mathrm{BsHR}_{2}$ and $\mathrm{BsHR}_{3}$ remain viable at $70^{\circ} \mathrm{C}$ up to 3 min while $\mathrm{BsHR}_{1}$ showed a definite decrease in the percent survivability at $70^{\circ} \mathrm{C}$ for $2 \mathrm{~min}$ and no viability was seen when exposed for $3 \mathrm{~min}$. However, EHR1, EHR2, and EHR3 isolates remained viable at $70^{\circ} \mathrm{C}$ up to $2 \mathrm{~min}$ with further inactivation when exposed for $3 \mathrm{~min}$. Mean phage titer of lysate ranged from $3 \times 10^{12}$ to $5 \times 10^{12} \mathrm{PFU} / \mathrm{ml}$.

\section{Host range of phage isolates}

Lytic activity of phage lysate against other bacteria is illustrated in Table-3. BsHR and $\mathrm{BsHR}_{2}$ were lytic against Staphylococcus, Salmonella, and Pseudomonas while $\mathrm{BsHR}_{3}$ was found effective against only two genera, viz., Staphylococcus and Pseudomonas. Among the five genera tested none of the bacteria was found sensitive to $\mathrm{EHR}_{3}$. EHR 2 showed lytic activity against Staphylococcus only while EHR 1 had wide host range.

\section{Discussion}

Likewise present study, various workers have isolated phages from sewage of livestock farms $[12,13]$. In accordance with the previous study, rapid screening methods such as turbidity reduction and streak plate methods and subsequent processing by DAL method $[12,14,15]$ were found much helpful during the
Table-2: Plaque morphology of phage lysates.

\begin{tabular}{lcl}
\hline $\begin{array}{l}\text { Phage } \\
\text { type }\end{array}$ & $\begin{array}{c}\text { Number } \\
\text { of isolates }\end{array}$ & Plaque morphology \\
\hline BSHR $_{1}$ & 22 & Small sized pin headed, clear plaque \\
$\mathrm{BSHR}_{2}$ & 5 & Small sized diffused/opaque plaque \\
$\mathrm{BSHR}_{3}$ & 3 & Large sized clear plaque \\
$\mathrm{EHR}_{1}$ & 1 & Small sized, clear plaque \\
$\mathrm{EHR}_{2}$ & 1 & Large sized diffused plaques \\
$\mathrm{EHR}_{3}$ & 1 & Elevated types haloed plaques \\
\hline
\end{tabular}

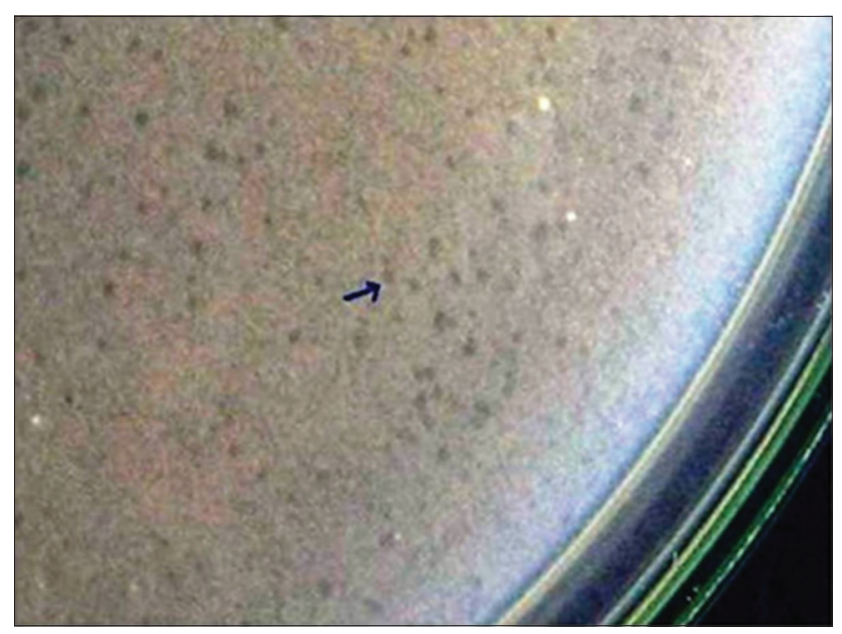

Figure-1: Small sized clear plaques on bacterial lawn $\left(\mathrm{BSHR}_{1}\right)$.

present investigation. This highlighted the importance of initial screening for successful recovery of phage. Failure of streak plate method to give 100\% recovery at par with that of turbidity reduction method may be attributed to less concentration of phages besides other factors, as large volume of sample is required for phage propagation. Those samples which failed to induce lysis of bacteria in turbidity reduction method also did not show plaque formation by streak plate method. Turbidity reduction method can be applied on crude sample and is comparatively convenient to perform and also is less time-consuming. However, the rapid turbidity reduction method alone was not found reliable as it frequently yielded false positive results also. Hence, simultaneous streak plate method that improved the recovery status of phage lysates is recommended. Most of the workers stressed on choice 


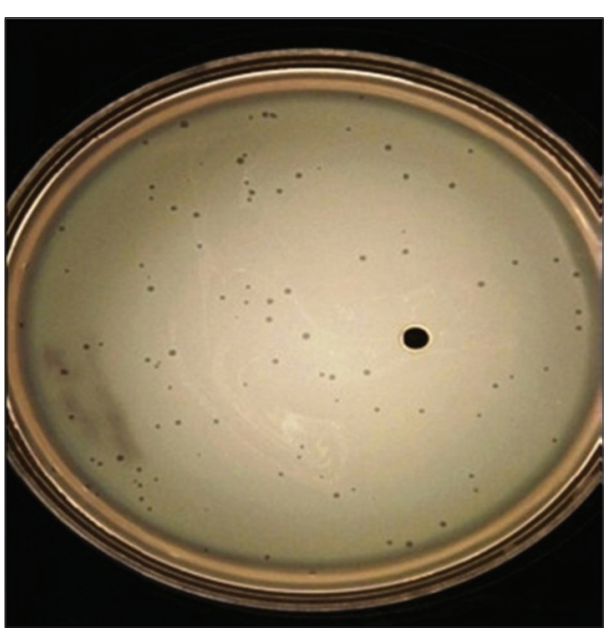

Figure-2: Small sized clear plaques on bacterial lawn $\left(\mathrm{EHR}_{1}\right)$.

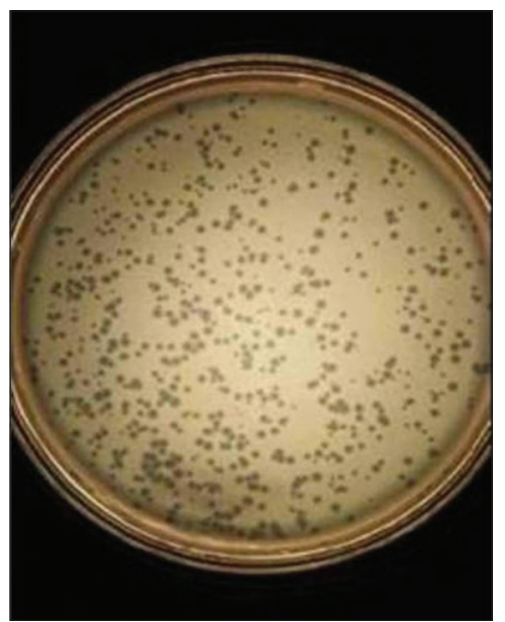

Figure-3: Large sized diffused plaques on bacterial lawn $\left(\mathrm{EHR}_{2}\right)$.

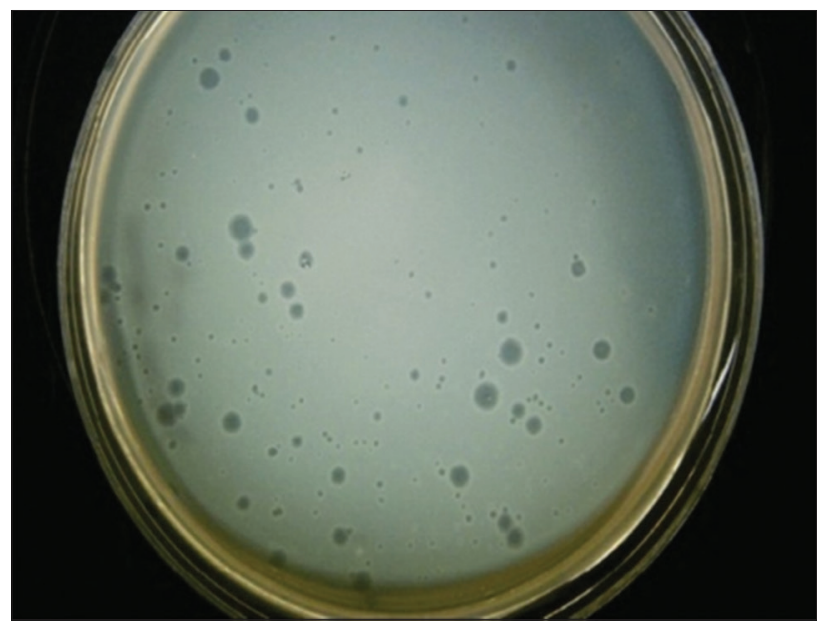

Figure-4: Elevated haloed plaques on bacterial lawn $\left(\mathrm{EHR}_{3}\right)$.

of appropriate host bacterium for optimum recovery of phages. There are several reports that support the use of either B. subtilis and/or E. coli $[16,17]$. B. subtilis supported the growth of multiple morphotypes of phages as compared to $E$. coli concluded on the basis of recovery of thirty B. subtilis (BsHR) phage and three
E. coli specific phages (EHR). Similarly, Krasowska et al. [18] reported that phage had the highest percent adsorption to the Bacillus host. Due to high activity at the low and high temperature and $\mathrm{pH}, B$. subtilis phage seems to be the best candidate for use in industry. Less recovery of $E$. coli phages may be correlated with the size of bacterium [13]. E. coli being smaller in size provides less surface area for attachment of bacteriophage as compared to B. subtilis.

Higher recovery status of phages in dairy farm waste as compared to buffalo farm waste is in support with report of Tiwari et al. [12], Shukla and Hirpurkar [13], and Askora et al. [19]. Higher concentration of phage in bottom and a middle layer of tank were also reported by Carey-Smith et al. [20] and Shukla and Hirpurkar [13]. Goyal et al. [21] opined that most of the organic matter settles in the deeper layer, thus providing optimum conditions for multiplication of host bacteria in deeper layer, which in turn, improves host range interaction.

Plaque morphology is one of the foremost criteria for characterization of phages [13]. Variation in the plaque morphology during the present study may correspond to the difference in phage strain, gel strength and addition of cation [12,22]. In contrast, Jothikumar et al. [8] found that plaque morphology was not affected by addition of cations. Pedroso and Martins [23] also did not find any relationship between coliphage family and specific plaque morphology.

Present findings are in accordance with earlier reports of Tiwari et al. [12] and Shukla and Hirpurkar [13] who observed that phage viability was maximal between $\mathrm{pH} 5$ and 9 and all phages were completely inactivated at $\mathrm{pH}$ of 3 and 11. Likewise, Ibrahim et al. [24] observed stable lytic activities at $\mathrm{pH}$ 6-8. On the contrary, Krasowska et al. [18] reported $B$. subtilis phages resistant to the acidic (4.0) and alkaline (9.0 and 10.0) pH. Low $\mathrm{pH}$ reportedly affects phage aggregation and reduces their abilities to penetrate the host cells [25].

Temperature susceptibility of phages in present findings is in conformity to those reported by Tiwari et al. [12] and Shukla and Hirpurkar [13]. Likewise, Lu et al. [26] have also reported that phages get inactivated at $70^{\circ} \mathrm{C}$ and above, while our findings are contradictory to those reported by Krasowska et al. [18] who found that phages of Bacillus were resistant to high temperatures $\left(80^{\circ} \mathrm{C}\right.$ for $\left.1 \mathrm{~min}\right)$. The reduction of burst size at higher temperature is probably the result of the effect of higher temperature on the metabolism of the host because the bacterial growth rate is decreased between $45^{\circ} \mathrm{C}$ and $51^{\circ} \mathrm{C}$. Likewise present study, many other workers have obtained high titer phage lysate [26,27].

Wide host range and phage types reported during present study are in conformity to the reports of Bielke et al. [28] who observed that phage host range is not always genera restricted, so phages could have wide host range. Present observations are in partial 
Table-3: Host range of phage isolates.

\begin{tabular}{|c|c|c|c|c|c|c|}
\hline Phage type & $\begin{array}{c}\text { Number of phage } \\
\text { isolates }\end{array}$ & S. aureus & Salmonella spp. & P. aeruginosa & Klebsiella spp. & Proteus spp. \\
\hline $\mathrm{BsHR}_{1}$ & 22 & 14 & 8 & 18 & 0 & 0 \\
\hline $\mathrm{BsHR}_{2}$ & 5 & 4 & 2 & 4 & 0 & 0 \\
\hline $\mathrm{BsHR}_{3}$ & 3 & 3 & 0 & 3 & 0 & 0 \\
\hline Total & 30 & 21 & 10 & 25 & 0 & 0 \\
\hline $\mathrm{EHR}_{1}$ & 1 & 1 & 1 & 1 & 1 & 1 \\
\hline $\mathrm{EHR}_{2}$ & 1 & 1 & 0 & 0 & 0 & 0 \\
\hline $\mathrm{EHR}_{3}$ & 1 & 0 & 0 & 0 & 0 & 0 \\
\hline Total & 3 & 2 & 1 & 1 & 1 & 1 \\
\hline
\end{tabular}

S. aureus=Staphylococcus aureus, $P$. aeruginosa $=P$ seudomonas aeruginosa

conformity with Carey-Smith et al. [20] who had reported narrow range phages restricted to maximum of two bacterial species. During the last decade, a marked increase in the number of identified phages has been observed. More than 200 lytic Staphylococcal phages have been characterized [29]. Present findings are supported by earlier studies also in which phages were recorded against Streptococci [30], E. coli and other enterobacteria [31], Pseudomonas [32], S. aureus [33], and Bacillus [16].

\section{Conclusion}

This study isolated and characterized phages from dairy farm waste disposal using $E$. coli and $B$. subtilis as the host system. Recovered phage lysate had broad host range displaying their potential to be used as therapeutics in infectious diseases. However, there is need to understand in vivo phage-mediated selection.

\section{Authors' Contributions}

RKS and SDH designed the experiment. Sample collection was done by RKS and VP. Media preparation and laboratory analysis were performed by RKS, $\mathrm{CS}$, and NR under the supervision of SDH. All authors read and approved the final manuscript.

\section{Acknowledgments}

The authors are very much thankful to the Dean, College of Veterinary Science and A.H., Anjora, Durg (Chhattisgarh) for providing financial support and all necessary facilities for conducting this research work.

\section{Competing Interests} interests.

The authors declare that they have no competing

\section{References}

1. Zhan, A., Buchan, A. and Chen, F. (2015) Novel N4 bacteriophages prevail in the cold biosphere. Appl. Environ. Microbiol., 81: 5196-5202.

2. Naghavi, N.S., Golgoljam, M. and Akbari, M. (2013) Effect of three sewage isolated bacteriophages on the multi drug resistant pathogenic bacteria. J. Biol. Sci., 13: 422-426.

3. WHO. (2014) Antimicrobial Resistance: Global Report on Surveillance. World Health Organization. Available from: http://www.who.int/drugresistance/documents/AMR report_Web_slide_set.pdf?ua=1. Accessed on 09-08-2017.

4. Clarke, T. (2003) Drug companies snub antibiotics as pipeline threatens to run dry. Nature, 425: 225.

5. O'Flynn, G., Ross, R.P., Fitzgerald, G.F. and Coffey, A. (2004) Evaluation of a cocktail of three bacteriophages for biocontrol of Escherichia coli O157:H7. Appl. Environ. Microbiol., 70: 3417-3424.

6. Holmfeldt, K., Middelboe, M., Nybroe, O. and Riemann, L. (2007) Large variabilities in host strain susceptibility and phage host range govern interactions between lytic marine phages and their Flavobacterium hosts. Appl. Environ. Microbiol., 73: 6730-6739.

7. Beke, G., Stano, M. and Klucar, L. (2016) Modelling the interaction between bacteriophages and their bacterial hosts. Math. Biosci., 279: 27-32.

8. Jothikumar, N., Reddy, C.G., Sundaria, R.B. and Saigopalb, D.V.R. (2000) Isolation of coliphages specific to enterotoxigenic E. coli (ETEC). J. Environ. Monit., 2: $372-374$

9. Harrigan, W.F. and McCance, M.E. (1993) Laboratory Methods in Food Dairy Microbiology. Academic Press, Harcourt Brace and Company Publishers, London, U.K. p52-57.

10. Adams, M.H. (1959) Discovery of bacteriophages and methods of study of bacterial viruses. Bacteriophages. Vol. 42. Interscience Publication, New York. p447-448.

11. Ellis, C.B. and Winters, A.L. (1969) Isolation of potential MS2 bacteriophage strains. Biol. Sci., 85: 336-345.

12. Tiwari, R., Hirpurkar, S.D. and Shakya, S. (2010) Isolation and characterization of lytic phage from natural waste material of livestock. Indian Vet. J., 87: 644-646.

13. Shukla, S. and Hirpurkar, S.D. (2011) Recovery status of bacteriophages of different livestock farms of Veterinary College, Adhartal, Jabalpur, India. Vet. World, 4(3): 117-119.

14. Verma, H., Pramod, D., Abbas, M., Prajapati, A., Ramchandra, D. and Rawat, M. (2013) Isolation and partial characterization of lytic phage against Salmonella abortusequi. Vet. World, 6(2): 72-75.

15. Mattila, S., Ruotsalainen, P. and Jalasvuori, M. (2015) On-demand isolation of bacteriophages against drug-resistant bacteria for personalized phage therapy. Front. Microbiol., 6: 1271.

16. Yuan, Y., Gao, M., Wu, D., Liu, P. and Wu, Y. (2012) Genome characteristics of a novel phage from Bacillus thuringiensis showing high similarity with phage from Bacillus cereus. PLoS One, 7(5): 375-557.

17. Gillis, A. and Mahillon, J. (2014) Phages preying on Bacillus anthracis, Bacillus cereus, and Bacillus thuringiensis: Past, present and future. Viruses, 6: 2623-2672.

18. Krasowska, A., Biegalska, A., Augustyniak, D., Los, M., Richert, M. and Lukaszewicz, M. (2015) Isolation and characterization of phages infecting Bacillus subtilis. Biomed. Res. Int., 2015: Article ID: 179597, 10.

19. Askora, A., Merwad, A., Gharibe, R.M. and Maysa, A.I.A. (2015) A lytic bacteriophage as a biocontrol for some enter pathogenic and enter hemorrhagic Escherichia coli strains of zoonotic risk in Egypt. Revue Méd. Vét., 166(34): 76-83.

20. Carey-Smith, G.V., Billington, C., Cornelius, A.J., 
Hudson, J.A. and Heinemonn, J.A. (2006) Isolation and characterization bacteriophages and infecting Salmonella spp. FEMS Microb. Lett., 258: 182-186.

21. Goyal, S.M., Gerba, C.P. and Bitton, G. (1987) In: Phage Ecology. John Wiley and Sons, New York. p321.

22. Ghasemian, A., Bavand, M. and Moradpour, Z. (2017) A broad-host range coliphage against a clinically isolated E. coli O157: Isolation and characterization. J. Appl. Pharm. Sci., 7(3): 123-128.

23. Pedroso, D.M.M. and Martins, M.T. (1995) Ultramorphology of coliphages isolated from water. Water Res., 29: 1199-1202.

24. Ibrahim, W.N.W., Aznan, A.S., Saari, N.A., Leong, L.K., Musa, N., Razzak, L.A., Danish-Daniel, M., Zainathan, S.C., Din, M.S.M., Ghaffar, M.A. and Musa, N. (2017) In-vitro characterization of lytic bacteriophage PhVh6 as potential biocontrol agent against pathogenic Vibrio harveyi. AACL Bioflux, 10(1): 64-76.

25. Langlet, J., Gaboriaud, F. and Gantzer, C. (2007) Effects of $\mathrm{pH}$ on plaque forming unit counts and aggregation of MS2 bacteriophage. J. Appl. Microbiol., 103: 1632-1638.

26. Lu, Z., Breidt, F., Fleming, H.P., Altermann, E. and Klaenhammer, T.R. (2003) Isolation and characterization of a Lactobacillus plantarum bacteriophage phiJL-1, from a cucumber fermentation. Int. J. Food Microbiol.,
84: 225-235.

27. McLaughlin, M.R., Balaa, M.F., Sims, J. and King, R. (2006) Isolation of Salmonella Bacteriophages from swine effluent lagoons. J. Environ. Qual., 35: 522-528.

28. Bielke, H., Donoghue, S., Donoghue, A. and Hargis, D.B.M. (2007) Salmonella Host range of bacteriophges that infect multiple genera. Poult. Sci., 86: 2536-2540.

29. Ackermann, H.W. (2007) Phages examined in the electron microscope. Arch. Virol., 152: 227-243.

30. Ahmed, K., Kaderbhai, N.N. and Kaderbhai, M.A. (2012) Bacteriophage therapy revisited. Afr. J. Microbiol. Res., 6(14): 3366-3379.

31. Marwa, B.S. and Abdulamir, A.S. (2014) In vitro study on using bacteriophages in the treatment of pathogenic Escherichia coli in Iraq. Iraqi J. Med. Sci., 12(2): 128-132.

32. Morello, E., Emilie, S., Damien, M., Michel, H., Laurent, T. and Lhousseine, D. (2011) Pulmonary bacteriophage therapy on Pseudomonas aeruginosa cystic fibrosis strains first steps towards treatment and prevention. PLoS One, 10: 13-71.

33. Garcia, P., Madera, C., Martinez, B., Rodriguez, A. and Suarez, J.E. (2009) Prevalence of bacteriophages infecting Staphylococcus aureus in dairy samples and their potential as biocontrol agents. J. Dairy Sci., 92: 3019-3026. 